\title{
Empirical Evidence Regarding the Effects of European Integration on Banks Efficiency
}

\author{
Alina Camelia Șargu and Angela Roman \\ Department of Economics and Business Administration, Faculty of Economics and Business \\ Administration, „Alexandru loan Cuza” University, lasi, Romania
}

\begin{abstract}
The academic literature suggests that the European integration process enhances the development of the economic environment in the case of the candidate countries. The banking sector represents, especially in the case of the new EU member countries, the backbone of the economy, as it is the main channel through which the economic undertakings are financed. Thus, in this context, the aim of our research is to analyse if the ascension to EU membership and the preparation for the adoption of the European single currency, in the case of Bulgaria and Romania, the two countries that have joined the EU in 2007, have determined an enhancement of the overall estimated efficiency of their banking sectors. In order to achieve this we have employed a non-parametric analysis, namely the Data Envelopment Analysis, using one of the most comprehensive samples of banks for this type of researches. The obtained results suggest that during the analysed period of time 2003-2010, the overall estimated banking efficiency for these countries has registered a slight improvement.
\end{abstract}

Keywords: Romania, Bulgaria, Data Envelopment Analysis, banks efficiency.

\section{Introduction}

The main political and economical characteristics that will dominate the European landscape in the near future are represented by the enlargement of the EU followed by the expansion of the euro zone. In order for professional and academics to have an overview of the effects that these processes will have on the European economy and especially in the case of the new EU member states it becomes necessary to investigate the performances that the countries from the same enlargement wave have registered, before and after their ascension.

Taking into consideration the complexity of these processes some most dramatic changes took place in the financial sector, which is considered the base of any modern economy. In the case of the European Union economy the banking sector represents the main channel, especially in the case of the new member countries, through which the economy is financed and implicitly it efficiency affects the growth rate of the economy (see Polouček, 2004). Thus, it becomes necessary for the existence of a stable and efficient banking system in order to allow for a smooth integration process and a smooth adoption of the European single currency. Other factors that have influenced tremendously the banking sector of the European Union member states and particular those of the new member states are represented by the liberalisation, globalisation and privatisation process, a large campaign of cross-border mergers and acquisitions and the adoption and implementation in practice of a wide range of financial innovations that aimed the enhancement of the overall banking efficiency. Despite the changes registered as a result of these evolutions, at its core the banking business is still defined as a financial intermediation 
process, namely the transformation of deposits into loans. Taking these into account, we considered an interesting subject for studying the impact that the ascension to full time membership of the European Union and the preparations for the adoption of the single currency had on the overall efficiency of the banks operating in the new EU member countries.

Thus, for a better understanding of the challenges posed by the ascension to full time membership of the European Union had on the banks efficiency from the new EU member states we have developed a paper that aims to comparatively analyse the evolutions registered by the banking sectors of the countries from the same EU enlargement wave. For this we have considered the usage of a non-parametric approach, taking into account the sample size which has varied during the analysed period of time namely because of the mergers and acquisitions that took place and also because of the assorted size of the analysed banks. Also the usage of the Data Envelopment Analysis allows us to obtain relevant results with just o small number of observations. This is more obvious in the case of Romania and Bulgaria, where since the 2007 enlargement wave, the number of existing banks is rather small in comparison with other new EU member states like Poland and Hungary.

The aim of our research is the underline the developments registered in the efficiency of the banks located in Romania and Bulgaria during the pre and post ascension period to full EU membership.

In order to achieve this the reminder of the paper is structured as follows: the first part contains the introduction remarks, the second part is dedicated to a literature review, the third part presents the methodology used in our research, the fourth part underlines the data used, the fifth part underlines the obtained empirical results and the sixth part is dedicated to the summary and concluding remarks.

\section{Literature Review}

There is a large academic literature dedicated to the subject of banks efficiency, the last two decades representing a particular period during which a large variety of methodological approaches and new way to quantify the efficiency of banks have been developed, the registered results being also extremely different: Berger et Humphrey (1997) and Berger et al. (1999). For the case of the United States there is a certain consent regarding the fact that the banks located on this market have improved their cost and profit efficiency mainly through the diminishing of the inefficiency that have prevented these institutions to achieve the maximal efficiency frontier (Berger et Humphrey, 1991; Berger et Mester, 1997) than through the optimisation of their scale and scope that generates a reduction of the overall costs and the maximization of the profits. There is also a series of other studies that provide alternative conceptual problems or are introducing also risk variables in the analysis (see Berg et al 1992; McAllister et McManus, 1993; Mester, 1996; Berger et DeYoung, 1997). A common characteristic of these studies is represented by the fact that they are focused solely on the case of one country, particularly on the example of the United States of America. Another approach on this topic underline that foreign owned banks tend to be less efficient than their domestic peers (e.g. Hasan and Hunter, 1996; Mahajan et al., 1996; DeYoung and Nolle, 1996; Chang et al., 1998; Peek et al., 1999). Still, this view is not universally shared, as there is a series of studies that conclude that especially in the case of emerging economies, the foreign owned banks tend to be more efficient than the domestic ones (see Grigorian and Manole, 2002; Hasan and Marton, 2003; Havrylchyk, 2005; Dardac et Boitan, 2008; Toçi, 2009).

By comparison with the number of studies undertaken at national level, the number of researches employing a cross-border analysis on banks efficiency is still rather low. The majority of the cross-border studies are focused on the Western Europe economies and also on comparison between these states and the US. Moreover the results of these studies tend to be different, being directly influenced by the size of the banks sample, the technique 
used for the estimation of the efficiency, the production function employed, the characteristics of the chosen inputs and outputs and nevertheless the observed period of time. Even though these researches are drawing a series of various conclusions a series of common characteristics can be identified. Thus, in the case of the Western European Countries, similar with the case of the United States, the average cost efficiency of banks is around $70-80 \%$, while the profit efficiency is relatively smaller at around $50-60 \%$. A good example for this is the research undertaken by Pastor et al (1997) that concludes that the average efficiency of the banks from France, Spain and Belgium is higher than the one obtained by the banks from Germany, Great Britain and Austria.

One of the most comprehensive studies undertaken on the subject of banks efficiency is represented by the research of the Sheldon (1999) which employees a sample of 1783 commercial and saving banks from the European Union, Norway and Switzerland, for the period 1993-1997. The author employ Data Envelopment Analysis (DEA) as a analysis method estimating the cost efficiency for the banks from the sample. The obtained results suggest that big banks, specialised banks and retail banks tend to be more efficient than small banks, diversified banks and wholesale banks. The estimated overall average efficiency of the banks from the sample was around $65 \%$ and the profit efficiency was lower, being slightly over $45 \%$. The banks from Denmark, France, Luxembourg and Sweden have registered the highest average estimated efficiency while the banks from Greece, Italy Portugal, Spain and Great Britain registers the lowest average estimated efficiency.

A similar approach is used by Altunbas et al. (2001) for the German banking system, the analysed period being 1989-1996. The authors have segmented the sample into commercial banks, public saving banks and mutual banks. This has allowed them to underline that German commercial banks tend to be more efficiency that the other three categories of banks.
Another ample research undertaken on the German banking market is represented by the one of Bos et al. (2005) and is focused on the effects that different accounting standards had on the registered heterogeneity of the estimated banks efficiency scores. The analysed period was 1993-2003, the authors concluding that differences on size, geographical dispersion and type of activity (commercial banks, cooperative banks and saving banks) determine extremely different efficiency scores. Another interesting conclusion is that the variation of the results is determined by the analysis method used in order to test for heterogeneity.

In order to avoid the differences that tend to appear in the case of the cross-border studies, there are several researches that incorporate into the analysis a series of indicators for the local economic environment (e.g.: Dietsch and LozanoVivas, 2000; Chaffai et al., 2001; LozanoVivas et al., 2001; Sathye, 2002; Grigorian and Manole, 2002; Lozano-Vivas et al., 2002).

A good example in this case is the research of Dietsch et Lozano-Vivas (2000) that concludes that the efficiency scores obtained using a common frontier in the case of two countries, without proper testing, tends to provide irrelevant results, because of the differences that exists between those countries in regard to their national regulations, demographical structure and economic conditions, these being factors for which the management of the banks cannot control for directly.

\section{Methodology}

The DEA method has been developed by Charnes et al. (1987). The authors have elaborated a linear programming mathematical model for the measurement of the optimal Pareto efficiency frontier. This approach has been created in order to determine the efficiency of an organization, using multiple measurements of the inputs and outputs that it uses (Banker et al, 1984). In the academic literature there are over 3000 researches and several books providing insight into the usage of the DEA 
method (Cooper, 2000; Phillips, 2005). Thus, it is clearly that this method has become a very popular measurement tool of the operational efficiency registered by the banking sector.

We will present in the following paragraphs a short description of the Data Envelopment Analysis. Assume that there is data on $\mathrm{K}$ inputs and $\mathrm{M}$ outputs for each of $\mathrm{N}$ banks. For $i$ bank these are represented by the vectors $x_{i}$ and $y_{i}$, respectively. Let us call the $K \times N$ input matrix $-X$, and the $M \times N$ output matrix $-Y$. To measure the cost efficiency for each bank we calculate a ratio of all outputs over all inputs, such as $\left(u / y_{i} / v / x_{i}\right)$ where $u$ is an $M$ $\mathrm{x} 1$ vector of output weights and $\mathrm{v}$ is a $K \mathrm{x} 1$ vector of input weights. To select optimal weights we specify the following mathematical programming problem:

$$
\begin{aligned}
& \max _{\mathrm{u}, \mathrm{v}}\left(\mathrm{u}{ }^{\mid} \mathrm{y}_{\mathrm{i}} / \mathrm{v}{ }^{\mid} \mathrm{x}_{\mathrm{i}}\right) \\
& u / y_{j} / v / x_{j} \leq 1, j=1,2, \ldots, N, \\
& u, v \geq 0
\end{aligned}
$$

The above formula has a problem of infinite solutions and therefore we impose the constraint $v / x_{i}=1$, which leads to:

$$
\begin{aligned}
& \max _{\mu, \rho}\left(\mathrm{u}^{\mid} \mathrm{y}_{\mathrm{i}} / \mathrm{v} \mid \mathrm{x}_{\mathrm{i}}\right) \\
& \rho^{\prime} x_{i}=1, \\
& \mu^{\prime} y_{i}-\rho^{\prime} x_{j} \leq 0, \quad j=1,2, \ldots, N,
\end{aligned}
$$

$\mu, \rho \geq 0$,

Where we change notation from $u$ and $v$ to $\mu$ and $\rho$, respectively, in order to reflect transformation.

Using the duality in linear programming, an equivalent envelopment form of this problem can be derived:

$$
\begin{aligned}
& \min _{\theta, \lambda} \theta \\
& -y_{i}+Y \lambda \geq 0, \\
& \theta x_{i}-X \lambda \geq 0, \\
& \lambda \geq 0,
\end{aligned}
$$

Where $\theta$ is a scalar and $\lambda$ is a vector of $N \times 1$ constants. The value of $\theta$ obtained will be the efficiency score for the $i$ bank, which will range between 0 and 1 . In should be noted that the problem should be solved $N$ times, ones for each bank.

\section{Data}

The sample that we have used in our research is one of the most comprehensive ones compared with the existing academic literature. The banks from our sample own together in average during the analysed period of time over $87 \%$ of the total banking assets from Romania and over $85 \%$ of the total banking assets of Bulgaria. A summary of these information are presented in table 1 . 
Table 1 - Summary Statistics of the Banks That are Active in Romania / Bulgaria and Part of Our Sample between 2003 and 2010

\begin{tabular}{|c|c|c|c|c|c|c|c|c|c|}
\hline & & 2003 & 2004 & 2005 & 2006 & 2007 & 2008 & 2009 & 2010 \\
\hline \multirow[b]{2}{*}{$\begin{array}{c}\text { Total } \\
\text { number } \\
\text { of banks } \\
\text { in our } \\
\text { sample }\end{array}$} & RO & 22 & 25 & 26 & 25 & 25 & 25 & 25 & 17 \\
\hline & BG & 17 & 18 & 21 & 23 & 21 & 24 & 24 & 17 \\
\hline \multirow[b]{2}{*}{$\begin{array}{c}\text { Total } \\
\text { number } \\
\text { of banks } \\
\text { (without } \\
\text { the } \\
\text { branches } \\
\text { of the } \\
\text { foreign } \\
\text { banks) }\end{array}$} & RO & 30 & 32 & 33 & 31 & 31 & 32 & 31 & 32 \\
\hline & BG & 29 & 29 & 28 & 28 & 24 & 24 & 24 & 24 \\
\hline \multirow[b]{2}{*}{$\begin{array}{l}\text { The } \\
\text { share } \\
\text { from the } \\
\text { total } \\
\text { assets } \\
\text { held by } \\
\text { the } \\
\text { banks } \\
\text { from our } \\
\text { sample }\end{array}$} & RO & $83,5 \%$ & $84,3 \%$ & $86,2 \%$ & $84,7 \%$ & $92,8 \%$ & $92,1 \%$ & $91,3 \%$ & $79,5 \%$ \\
\hline & BG & $75,50 \%$ & $93,63 \%$ & $86,48 \%$ & $81,21 \%$ & $84,74 \%$ & $91,53 \%$ & $91,82 \%$ & $87,95 \%$ \\
\hline
\end{tabular}

Source: Authors calculations based on annual reports of the banks and Bureau Van Dijk Bankscope data (https://bankscope2.bvdep.com)

Most of the researches that employ DEA are using the intermediation approach in order to define the core banking activities. Thus, also in our research we have employed the intermediation approach in order to define the inputs and outputs in a similar way with the one used by Sealey et Lindley (1977), making a series of adjustments for the particularities of our sample. Taking into account the sample size and the characteristics of the analysed banking sector, we have chosen three inputs (labour, capital and deposits) and two outputs (loans and net interest income) as presented in Figure 1.

Figure 1 - Inputs and Outputs for Data Envelopment Analysis

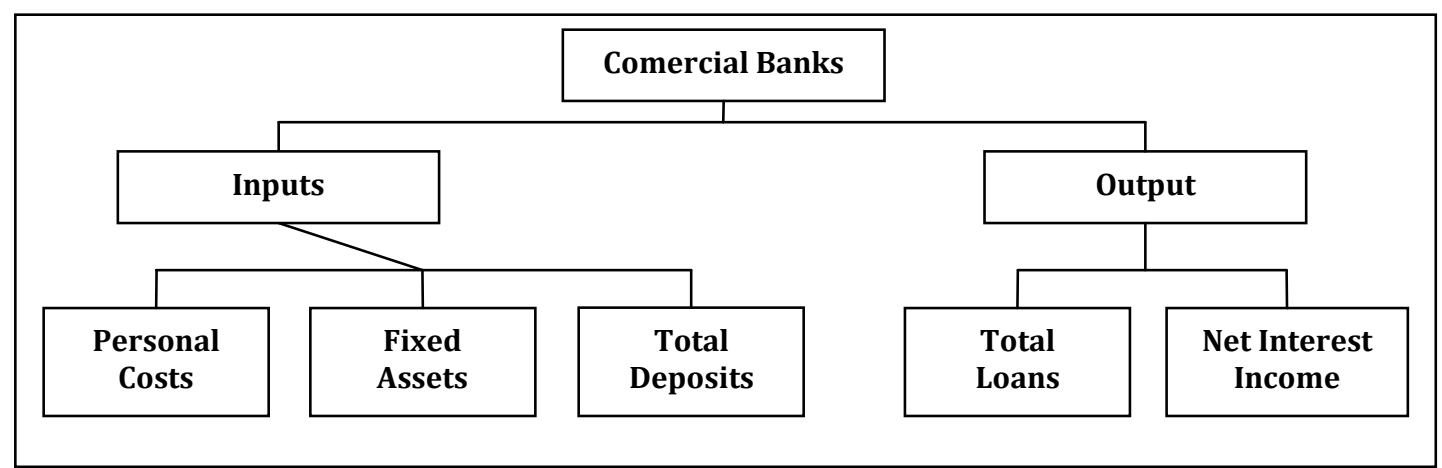

Source: Authors calculations 
Taking into account the characteristics and limits of a non-parametric analysis, we have considered inappropriate to chose a large number of inputs and output as this will have diminished the number of inefficient banks observed. Thus, as mention previous we have limited the number of inputs to three and the number of outputs to two. In our research we have defined labour as the total expenses on wages and bonuses of the personal (PC). We have defined capital as the book value of fixed assets (FA). Deposits were defined as the sum of time and demand deposits (TD). The net interest income is defined as the difference between interest incomes and interest expenses (NII). In table 2 we have surmised statistics for the inputs and the outputs used and also for the total banking assets for the period $2003-2010$.

Unlike the approached used by Sealey et Lindley (1977) we have removed the financial investment assets from the outputs mainly because in the case of the banks located in Romania and Bulgaria most of them tend to exclusively invest in governmental bonds and treasury bills, the capital markets of these countries not being able to provide sophisticated investment products. An additional argument in favour for this approach is represented by the fact that the value of these investments is extremely low in the overall balance sheet of the banks. In order to better underline not just the volume but also the quality of the intermediation process we have employed as an output in our model also the net interest income (NII). The data that we have used in our research are obtained from Bureau Van Dijk Bankscope database, the largest and comprehensive database on banks in the world and in some cases from the annual reports of the banks from our panel. 
Table 2 - Descriptive Statistics for the Inputs and Outputs from Our Research

\begin{tabular}{|c|c|c|c|c|c|c|c|c|c|c|c|}
\hline \multirow{8}{*}{ 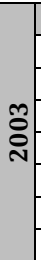 } & & \multicolumn{5}{|c|}{ Romania (22 banks) } & \multicolumn{5}{|c|}{ Bulgaria (17 banks) } \\
\hline & & mean & med & st.dev. & $\min$ & $\max$ & mean & med & st.dev. & $\min$ & $\max$ \\
\hline & TL & 295,49 & 101,70 & 525,26 & 3,44 & 2224,26 & 177,10 & 76,04 & 222,30 & 6,67 & 680,25 \\
\hline & NII & 34,59 & 11,73 & 68,65 & 0,21 & 306,50 & 16,33 & 4,52 & 23,82 & 1,13 & 72,24 \\
\hline & PC & 19,56 & 5,50 & 41,03 & 0,13 & 189,27 & 5,25 & 2,57 & 6,10 & 0,62 & 23,29 \\
\hline & FA & 53,62 & 8,35 & 118,79 & 0,13 & 496,56 & 17,18 & 6,11 & 26,30 & 0,97 & 82,45 \\
\hline & TD & 521,30 & 153,17 & 931,67 & 4,39 & 4212,73 & 296,77 & 142,02 & 419,57 & 0,87 & 1507,85 \\
\hline & TA & & & & & & 371,17 & 170,29 & 506,10 & 21,91 & 1854,64 \\
\hline \multirow{8}{*}{ ঠे } & & \multicolumn{5}{|c|}{ Romania (25 banks) } & \multicolumn{5}{|c|}{ Bulgaria (18 banks) } \\
\hline & & mean & med & st.dev. & $\min$ & $\max$ & mean & med & st.dev. & $\min$ & $\max$ \\
\hline & TL & 348,43 & 111,63 & 619,63 & 5,95 & 2656,27 & 278,94 & 121,79 & 329,65 & 15,00 & 1085,39 \\
\hline & NII & 40,52 & 11,68 & 79,00 & 0,37 & 358,19 & 23,38 & 8,50 & 30,78 & 0,92 & 103,26 \\
\hline & PC & 19,11 & 6,39 & 38,38 & 0,17 & 186,16 & 6,88 & 4,76 & 7,60 & 0,61 & 30,77 \\
\hline & FA & 45,58 & 9,08 & 99,71 & 0,22 & 438,87 & 17,99 & 5,94 & 23,87 & 0,67 & 79,05 \\
\hline & TD & 625,68 & 162,58 & 1113,85 & 7,18 & 5204,03 & 377,41 & 178,72 & 446,89 & 2,66 & 1419,09 \\
\hline & TA & & & & & & 487,15 & 229,25 & 555,39 & 22,58 & 1778,94 \\
\hline \multirow{8}{*}{ ᄂ2 } & & \multicolumn{5}{|c|}{ Romania ( 26 banks) } & \multicolumn{5}{|c|}{ Bulgaria ( 21 banks) } \\
\hline & & mean & med & st.dev. & $\min$ & $\max$ & mean & med & st.dev. & $\min$ & $\max$ \\
\hline & TL & 561,52 & 164,12 & 1005,35 & 10,85 & 4509,90 & 391,46 & 141,12 & 563,09 & 17,64 & 2196,85 \\
\hline & NII & 46,53 & 18,32 & 81,40 & 0,91 & 335,30 & 30,07 & 11,04 & 46,14 & 1,12 & 168,17 \\
\hline & PC & 26,38 & 8,91 & 50,24 & 0,33 & 244,72 & 8,69 & 5,27 & 11,47 & 0,31 & 43,87 \\
\hline & FA & 53,40 & 15,19 & 110,88 & 0,30 & 503,38 & 19,94 & 7,46 & 29,75 & 0,41 & 107,27 \\
\hline & TD & 960,35 & 254,81 & 1679,79 & 15,49 & 7707,72 & 532,75 & 245,58 & 761,98 & 1,69 & 3065,70 \\
\hline & TA & & & & & & 692,44 & 297,32 & 959,56 & 23,32 & 3906,13 \\
\hline \multirow{8}{*}{$\begin{array}{l}0 \\
\text { ¿̊ } \\
\text { ㄱ. }\end{array}$} & & \multicolumn{5}{|c|}{ Romania ( 25 banks) } & & & aria (23 ba & & \\
\hline & & mean & med & st.dev. & $\min$ & $\max$ & mean & med & st.dev. & $\min$ & $\max$ \\
\hline & TL & 959,19 & 294,63 & 1702,94 & 16,82 & 7209,23 & 415,75 & 207,84 & 494,30 & 10,74 & 1735,81 \\
\hline & NII & 65,30 & 27,48 & 111,45 & 1,19 & 478,27 & 415,75 & 207,84 & 494,30 & 10,74 & 1735,81 \\
\hline & PC & 33,82 & 15,12 & 55,67 & 0,57 & 261,53 & 8,59 & 5,62 & 9,15 & 0,46 & 33,08 \\
\hline & FA & 60,99 & 20,56 & 110,52 & 0,62 & 472,72 & 19,85 & 8,54 & 25,22 & 0,31 & 105,84 \\
\hline & TD & 1362,22 & 452,12 & 2377,55 & 24,31 & 10719,75 & 601,31 & 392,22 & 699,48 & 3,43 & 2671,64 \\
\hline & TA & & & & & & 761,91 & 471,52 & 858,79 & 23,93 & 3097,10 \\
\hline & & & & ania $(25 \mathrm{bc}$ & & & & & aria (21 ba & & \\
\hline & & mean & med & st.dev. & $\min$ & $\max$ & mean & med & st.dev. & $\min$ & $\max$ \\
\hline & TL & 1717,88 & 942,61 & 2596,88 & 22,43 & 11275,45 & 762,06 & 342,26 & 937,76 & 10,64 & 2901,78 \\
\hline$\hat{0}$ & NII & 87,59 & 45,15 & 140,04 & 1,44 & 588,52 & 46,81 & 19,17 & 57,83 & 1,23 & 196,65 \\
\hline 은 & PC & 48,20 & 23,15 & 76,24 & 1,29 & 357,87 & 11,86 & 7,31 & 13,14 & 0,56 & 49,54 \\
\hline & FA & 74,56 & 27,28 & 120,37 & 1,23 & 493,03 & 26,87 & 10,69 & 34,02 & 0,51 & 124,45 \\
\hline & TD & 2257,21 & 814,83 & 3520,30 & 30,01 & 15790,81 & 949,02 & 485,73 & 1108,39 & 10,48 & 3769,66 \\
\hline & TA & & & & & & 1219,26 & 555,12 & 1406,32 & 23,21 & 4643,06 \\
\hline & & & & ania $(25 \mathrm{bc}$ & & & & & aria (24 ba & & \\
\hline & & mean & med & st.dev. & $\min$ & $\max$ & mean & med & st.dev. & $\min$ & $\max$ \\
\hline & TL & 2044,14 & 1238,64 & 2904,84 & 23,24 & 12361,27 & 957,47 & 472,34 & 1196,79 & 14,16 & 3701,15 \\
\hline$\stackrel{\infty}{0}$ & NII & 111,32 & 55,04 & 184,60 & 1,71 & 825,61 & 53,79 & 24,24 & 70,04 & 1,02 & 237,14 \\
\hline 유 & PC & 50,41 & 24,93 & 66,30 & 1,68 & 285,40 & 12,14 & 8,56 & 15,31 & 0,72 & 52,87 \\
\hline & FA & 74,31 & 27,67 & 113,17 & 1,36 & 467,20 & 26,63 & 11,02 & 35,67 & 0,36 & 138,41 \\
\hline & TD & 2545,48 & 826,92 & 3608,03 & 35,87 & 15092,84 & 972,81 & 493,94 & 1270,72 & 14,93 & 4730,65 \\
\hline & TA & & & & & & 1261,62 & 678,39 & 1595,14 & 26,28 & 5641,78 \\
\hline & & & & ania $(25 \mathrm{bc}$ & & & & & aria (24 ba & & \\
\hline & & mean & med & st.dev. & $\min$ & $\max$ & mean & med & st.dev. & $\min$ & $\max$ \\
\hline & TL & 1711,87 & 1006,39 & 2619,48 & 17,85 & 11171,77 & 982,24 & 470,96 & 1186,76 & 12,63 & 3772,73 \\
\hline 。 & NII & 118,32 & 62,81 & 197,82 & 1,23 & 905,28 & 56,31 & 23,29 & 70,54 & 1,07 & 240,92 \\
\hline กั & PC & 38,44 & 25,71 & 54,76 & 1,32 & 217,39 & 14,03 & 8,23 & 14,58 & 0,77 & 50,01 \\
\hline & FA & 63,44 & 26,13 & 97,95 & 0,99 & 407,23 & 29,44 & 12,14 & 38,10 & 0,39 & 142,14 \\
\hline & TD & 2316,87 & 655,18 & 3179,19 & 36,75 & 13385,15 & 1085,74 & 485,10 & 1321,18 & 19,02 & 4871,20 \\
\hline & TA & & & & & & 1385,51 & 685,19 & 1637,58 & 31,14 & 5892,06 \\
\hline & & & & ania (17 b & & & & & aria (17 ba & & \\
\hline & & mean & med & st.dev. & $\min$ & $\max$ & mean & med & st.dev. & $\min$ & $\max$ \\
\hline & TL & 2367,28 & 1288,35 & 2996,29 & 27,70 & 11251,53 & 1345,20 & 848,24 & 1214,83 & 69,48 & 3851,87 \\
\hline 윽 & NII & 168,038 & 71,056 & 229,43 & 1,23 & 890,22 & 80,12 & 39,26 & 79,30 & 4,70 & 253,50 \\
\hline กิ & PC & 57,60 & 29,39 & 58,66 & 2,08 & 207,42 & 18,18 & 14,316 & 15,51 & 0,86 & 49,54 \\
\hline & FA & 83,70 & 30,93 & 109,70 & 0,99 & 402,14 & 37,45 & 25,71 & 40,78 & 0,25 & 144,64 \\
\hline & TD & 3110,09 & 1526,96 & 3645,23 & 36,98 & 14161,79 & 1529,05 & 1209,63 & 1316,06 & 64,88 & 4676,39 \\
\hline & TA & & & & & & 1949,82 & 1380,45 & 1650,66 & 101,34 & 5798,54 \\
\hline
\end{tabular}


In order to provide comparability between the banking data we have transformed all the values used from national currencies into euro, employing the official exchange rate of the European Central Bank, the exchange rate course being presented for each year in table 3. This approach has been used previous in the academic literature being considered appropriate for similar comparative cross-border studies (e.g. Berg et al, 1993; Stavárek, 2006).

Table 3 - Official Annual Exchange Rate for EUR/BGN and EUR/RON

\begin{tabular}{|l|c|c|c|c|c|c|c|c|}
\hline & $\mathbf{2 0 0 3}$ & $\mathbf{2 0 0 4}$ & $\mathbf{2 0 0 5}$ & $\mathbf{2 0 0 6}$ & $\mathbf{2 0 0 7}$ & $\mathbf{2 0 0 8}$ & $\mathbf{2 0 0 9}$ & $\mathbf{2 0 1 0}$ \\
\hline EUR/BGN & 1,9490 & 1,9533 & 1,9558 & 1,9558 & 1,9558 & 1,9558 & 1,9558 & 1,9558 \\
\hline EUR/RON & 3,7550 & 4,0509 & 3,6209 & 3,5258 & 3,3353 & 3,6826 & 4,2399 & 4,2122 \\
\hline
\end{tabular}

Source: European Central Bank Statistical Data Warehouse (http://sdw.ecb.europa.eu)

\section{Empirical Findings}

Employing the methodology and data presented previous we have estimated the overall efficiency for all the banks from our sample using the DEA approach, making separate estimation for the CRS and VRS models respectively. In order to compute the efficiency scores for the banks from our sample we have used EMS software, version 1.3.0 developed by Holger Scheel. Taking the cross-border nature of our research we have employed a common efficiency frontier for all the banks from our sample, this allowing us to underline the existing efficiency differences across the analysed banking sectors. This approach is in line with the existing academic literature on this subject (e.g. Berg et al., 1993; Pastor et al., 1997; Casu and Molyneux, 2000; Grigorian and Manole, 2002 or Stavárek, 2006). In table 4 we have presented the descriptive statistics for the efficiency scores obtained in the case of the CRS and VRS models, respectively.

At a fist look we can observe that the VRS efficiency scores are considerably higher than the CRS ones while also more DMU being on the efficiency frontier in the case of the VRS model than in the case of the CRS model. We must underline that the CRS assumption can be accepted without reserves only if the analysed banks are operating at their optimal size. A series of factors like imperfect competition, taxation, financial and juridical constrains, central banks regulations and supervision authorities, concentration and structure of the market and also a wide range of other factors influence the banks efficiency, these implicitly making them operate not at their optimal size. This is underlined also in the academic literature were a series of studies provide empirical evidence on the shortages of the CRS model (see: McAlister et McManus, 1993; Wheelock et Wilson, 1999). In this context and taking into account the characteristics of the analysed banking sectors we consider that the efficiency scores estimated using the VRS model can provide more insight for our research. During the analysed period of time 2003-2010 we were able to detect an improvement of the average efficiency score. The obtained results are in accordance with previous academic studies on this topic (see: Sargu et Roman, 2011). 
Table 4 - Descriptive Statistics of Efficiency Scores for the CRS and VRS Model

\begin{tabular}{|c|c|c|c|c|c|c|c|c|}
\hline \multirow{9}{*}{ 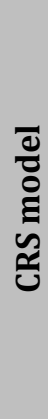 } & & No. DMUs & $\begin{array}{l}\text { No. Effic. } \\
\text { DMU }\end{array}$ & mean & med & st.dev. & $\min$ & $\max$ \\
\hline & 2003 & 34 & 4 & 0,567 & 0,510 & 0,229 & 0,248 & 1,000 \\
\hline & 2004 & 43 & 6 & 0,576 & 0,505 & 0,231 & 0,190 & 1,000 \\
\hline & 2005 & 47 & 4 & 0,441 & 0,396 & 0,233 & 0,096 & 1,000 \\
\hline & 2006 & 48 & 4 & 0,450 & 0,411 & 0,212 & 0,168 & 1,000 \\
\hline & 2007 & 46 & 4 & 0,486 & 0,432 & 0,221 & 0,197 & 1,000 \\
\hline & 2008 & 49 & 7 & 0,507 & 0,418 & 0,249 & 0,179 & 1,000 \\
\hline & 2009 & 49 & 5 & 0,520 & 0,475 & 0,247 & 0,177 & 1,000 \\
\hline & 2010 & 34 & 5 & 0,639 & 0,655 & 0,228 & 0,249 & 1,000 \\
\hline \multirow{9}{*}{ 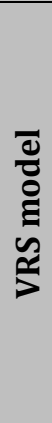 } & & No. DMUs & $\begin{array}{l}\text { No. Effic. } \\
\text { DMU }\end{array}$ & mean & med & st.dev. & $\min$ & $\max$ \\
\hline & 2003 & 34 & 17 & 0,812 & 0,978 & 0,243 & 0,289 & 1,000 \\
\hline & 2004 & 43 & 17 & 0,749 & 0,777 & 0,247 & 0,200 & 1,000 \\
\hline & 2005 & 47 & 13 & 0,695 & 0,733 & 0,274 & 0,099 & 1,000 \\
\hline & 2006 & 48 & 12 & 0,718 & 0,777 & 0,243 & 0,224 & 1,000 \\
\hline & 2007 & 46 & 15 & 0,743 & 0,764 & 0,239 & 0,249 & 1,000 \\
\hline & 2008 & 49 & 16 & 0,720 & 0,724 & 0,257 & 0,184 & 1,000 \\
\hline & 2009 & 49 & 16 & 0,758 & 0,779 & 0,233 & 0,211 & 1,000 \\
\hline & 2010 & 34 & 14 & 0,806 & 0,894 & 0,238 & 0,251 & 1,000 \\
\hline
\end{tabular}

Source: Authors calculations

The low efficiency scores registered by the banks from our sample, especially in the case of Bulgaria is determined by the caution approach that the banks located in these countries had regarding their lending activity. This evolution is not a surprise, as the banks in these countries have faced difficulties regarding the enforcement of creditor rights, uncertainties in the process of obtaining information about debtors and also have a history of hesitant reforms in the corporate sector. Also, the recent financial turmoil has determined the banks to diminish their exposure to the market, thus low risk activities like foreign exchange, interbank transactions, insurance and investments in government bonds being preferred lately, instead of classical lending activities. This had determine the manifestation of an eviction effect in the economy, the lending to the private sector and especially to retail customers and small and medium size enterprises being crowded out. This extra safe attitude of the banks from our sample is also underline by the short maturity of their loans portfolio, almost half of their total loans having a maturity of under a year. The risk aversion which negatively impacts the efficiency of the panel banks is also enhanced by the effects of the financial and economic turmoil, the capital adequacy in the analysed countries exceeding the limits as well as good practice standards (Basel requirements) substantially.

\section{Concluding Remarks}

Concluding, the ascension process to membership of the European Union and the preparation period for the adoption of the euro have a positive impact on the overall estimated efficiency of the banks that operate in Romania and Bulgaria. Despite these, there are several precautions that must be underlined. First, the overall performance of the banks can be influenced by a variety of factors, some of which cannot be influenced by the managerial team and some of which are not related in any way to the European integration process. Second, a major factor that impacts the overall estimated efficiency of the banks located in Romania and Bulgaria is represented by the juridical and economical environment of these countries and also by the fact that these economies are still in the emerging phase. Still, the ascension process has determined these countries to undertake the necessary reforms in the juridical system, to stabilise the economic environment and thus 
improve the environment in which banks operate. These positive evolutions have been underlined in our research by the improvement of the overall estimated efficiency of the banks from these countries. The academic added value of our studies is represented mainly by the way in which it analysis the efficiency of the banks from the two countries (Bulgaria and Romania) that have recently joined the European Union. Further studies on this subject could provide more insight into the way in which the current sovereign debt crisis impacts the overall estimated efficiency of the banks that operate in Romania and Bulgaria.

\section{References}

Altunbas, Y., Ming-Hau, L., Molyneux, P. \& Seth, R. (2000). "Efficiency and Risk in Japanese Banking," Journal of Banking and Finance, 24, 1605-1628.

Banker, R. D., Charnes, A. \& Cooper, W. W. (1984). "Some Models for Estimating Technical and Scale Inefficiencies in Data Envelopment Analysis," Management Science, Vol. 30 No. 9, 1078-1092.

Berger, A. N. \& DeYoung, R. (1997). "Problem Loans and Cost Efficiency in Commercial Banks," Journal of Banking and Finance, 21, 849-870.

Berger, A. N. \& Humphrey, D. B. (1997). "Efficiency of Financial Institutions: International Survey and Directions for Future Research," European Journal of Operational Research, 98, 175-212.

Berger, A. N. \& Mester, L. J. (1997). "Inside the Black Box: What Explains Differences in the Efficiencies of Financial Institutions?," Journal of Banking and Finance, 21, 895947.

Berg, S. A., Forsund, F. R., Hjarmarsson, L. \& Suominen, M. (1993). "Banking Efficiency in the Nordic Countries," Journal of Banking and Finance, 17, 371-388.

Bos, J. W. B. \& Kolari, J. W. (2005). "Large Bank Efficiency in Europe and the United States: Are There Economic Motivations for
Geographic Expansion in Financial Services?," Journal of Business, No.78/Vol. 4, 1555-1592.

Camelia, S.. A. \& Angela, R. (2011). Financial Innovation and the Romanian Banking Sector Efficiency in the Context of the Financial Crisis: Foreign Versus Domestic Banks, In: Polouček, S. and Stavárek, D. (Ed.), Lessons Learned from the Financial Crisis. Proceedings of 13th International Conference on Finance and Banking, P. 548-565.

Chaffai, M. E., Dietsch, M. \& Lozano-Vivas, A. (2001). "Technological and Environmental Differences in the European Banking Industries," Journal of Financial Services Research, 19 (2/3), 147-162.

Chang, C. E., Hasan, I. \& Hunter, W. C. (1998). "Efficiency of Multinational Banks: An Empirical Investigation," Applied Financial Economics, 8, 1-8.

Charnes, A., Cooper, W. W. \& Rhodes, E. (1978). "Measuring the Efficiency of Decision Making Units," European Journal of Operational Research, Vol. 2 No. 2, 429444.

Chudy, K., Sobolewski, M. \& Stępień, K. (2012). "Changes in the Productivity of Banks Situated in Poland During the Years Preceding the Financial Crisis," Bank I Kredyt, Vol. 43, No. 2, 5-24.

Cooper, W. W., Seiford, L. M. \& Tone, K. (2000). Data Envelopment Analysis: A Comprehensive Text With Models, Applications, References, and DEA-Solver Software, Boston: Kluwer Academic Publishers.

Dardac, N. \& Boitan, I. (2008). "Evaluation of Individual and Aggregate Credit Institutions Management's Performance," Economie Teoretică Și Aplicată, 5 (522).

DeYoung, R. \& Nolle, D. E. (1996). "ForeignOwned Banks in the U.S.: Earning Market Share or Buying It?," Journal of Money, Credit and Banking, 27, 622-36. 
Dietsch, M. \& Lozano-Vivas, A. (2000). "How the Environment Determines Banking Efficiency: A Comparison between French and Spanish Industries," Journal of Banking and Finance, 24, 985-1004.

Fang, Y., Hasan, I. \& Marton, K. (2011). Bank Efficiency in Transition Economies: Recent Evidence from South-Eastern Europe, Bank of Finland Research Discussion Papers, No. 5.

Grigorian, D. A. \& Manole, V. (2002). "Determinants of Commercial Bank Performance in Transition: An Application of Data Envelopment Analysis," IMF Working Paper, 146 (2).

Hasan, I. \& Hunter, W. C. (1996). 'Efficiency of Japanese Multinational Banks in the United States,' Research in Finance, 14, 157 173.

Hasan, I. \& Marton, K. (2003). "Development and Efficiency of the Banking Sector in a Transitional Economy: Hungarian Experience," Journal of Banking and Finance, 27, 2249-2271.

Havrylchk, O. (2006). "Eficiency of the Polish Banking Industry: Foreign Versus Domestic Banks," Journal of Banking and Finance, 30, 1975-1996.

Košak, M., Zajc, P. \& Zorić, J. (2009). "Bank Efficiency Differences in the New EU Member States," Baltic Journal of Economics, Vol. 9, No. 2, 67-90.

Lozano-Vivas, A., Pastor, J. T. \& Hasan, I. (2001). "European Bank Performance Beyond Country Borders: What Really Matters?," European Finance Review, Vol.5 (1/2), 141-165.

Lozano-Vivas, A., Pastor, J. T. \& Pastor, J. M. (2002). "An Efficiency Comparison of European Banking Systems Operating Under Different Environmental Conditions," Journal of Productivity Analysis, Vol. 18 No. 1, 59-77.

Mahajan, A., Rangan, N. \& Zardkoohi, A. (1996). "Cost Structures in Multinational and Domestic Banking," Journal of Banking and Finance, 20, 238-306.

McAllister, P. H. \& McManus, D. (1993). "Resolving the Scale Efficiency Puzzle in Banking," Journal of Banking and Finance, 27, 389-405.

Mester, L. J. (1996). "A Study of Bank Efficiency Taking into Account RiskPreferences," Journal of Banking and Finance, 20, 1025-1045.

Pastor, J. M., Perez, F. \& Quesada, J. (1997). "Efficiency Analysis in Banking Firms: An International Comparison," European Journal of Operational Research, 2C, 395407.

Peek, J., Rosengren, E. S. \& Kasirye, F. (1999). "The Poor Performance of Foreign Bank Subsidiaries: Were the Problems Acquired or Created?," Journal of Banking and Finance, 22, 799-819.

Phillips, F. (2005). "25 Years of Data Envelopment Analysis," International Journal of Information Technology and Decision Making, No. 3 Vol. 4, 317-323.

Polouček, S. (2003). (Ed.) Reforming the Financial Sector in Central European Countries, Houndmills: Palgrave Macmillan.

Sathye, M. (2001). "X-Efficiency in Australian Banking: An Empirical Investigation," Journal of Banking and Finance, 25, 613-630.

Sealey, C. W. \& Lindley, J. T. (1977). "Inputs, Outputs, and a Theory of Production and Cost at Depository Financial Institutions," The Journal of Finance, 32 (4), 1251-1265.

Sheldon, G. (1999). 'Costs, Competitiveness and the Changing Structure of European Banking,' Fondation Banque De France Pour La Recherche Working Paper, Paris, France.

Stavárek, D. (2006). "Banking Efficiency in the Context of European Integration," Eastern European Economics, No. 4 Vol. 44, 5-31. 
Sum, K. (2012). "The Integration of the Financial Markets and Growth Evidence from a Global Cross-Country Analysis," Bank I Kredyt, Vol. 43, No. 3, 47-70.

Toçi, V. Z. (2009). "Efficiency of Banks in South-East Europe: With Special Reference to Kosovo," CBK Working Paper, 4. 